\title{
REDEFINISI KAUM PADERI MELALUI METODOLOGI GENEALOGIS FOUCAULDIAN SEBAGAI REKONSILIASI ETNIS MINANGKABAU-BATAK
}

\author{
Alfi Arifian ${ }^{1}$
}

\begin{abstract}
Redefinition upon "Kaum Paderi" is back-grounded by historical conflict of long-term aftermath in Paderi War involving two major Sumatran races, Minangkabau and Batak, which remains closed conflict caused by ambiguous local historical sources, tambo (Minang term) or turi-turian (Batak term). Upon the emergence of book authored by Ir. Mangaraja Onggang Parlindungan (MOP) entitled "Tuanku Rao; Teror Agama Islam Mazhab Hambali di Tanah Batak 1816-1833" which was firstly published in 1964 sharpened this closed conflict issue. Hamka then responded with "Antara Fakta dan Khayal: Tuanku Rao" in 1974 as he attempted to reduce conflict and deny public perception constructed through Parlindungan's book about Minang people's viciousness during the propagation campaign of "Kaum Paderi".
\end{abstract}

Redefinition upon "Kaum Paderi" through genealogical methodology is the root of solution to change mindset with final result of reconciliation between Minangkabau and Batak. The product of this theory can change the course of history and giving comprehension to the people about dichotomy in Paderi.

Keywords: redefinition, Kaum Paderi, genealogical methodology, reconciliation

\begin{abstract}
Abstrak
Redefinisi Kaum Paderi ini dilatarbelakangi konflik masa lalu Paderi yang memiliki dampak jangka panjang hingga melibatkan dua etnis besar Sumatera; Minangkabau dan Batak yang menyisakan konflik tertutup akibat pendidikan lokal yang rancu, yakni tambo (istilah Minang) atau turi-turian (istilah Batak). Munculnya buku karya Ir. Mangaraja Onggang Parlindungan (MOP) berjudul "Tuanku Rao; Teror Agama Islam Mazhab Hambali di Tanah Batak 1816-1833" yang terbit pertama kali tahun 1964 semakin mempertajam isu konflik tertutup ini. Hamka pun membalas dengan buku "Antara Fakta dan Khayal: Tuanku Rao" tahun 1974 sebagai usaha mereduksi konflik dan untuk menepis persepsi publik yang terbangun oleh buku MOP mengenai kekejaman bangsa Minang selama dakwah Kaum Paderi.
\end{abstract}

Redefinisi Kaum Paderi melalui metodologi genealogis merupakan akar solusi untuk mengubah pola pikir dengan pencapaian akhir rekonsiliasi antara etnis MinangkabauBatak. Luaran hasil teori redefinisi ini bisa mengubah arah sejarah serta memberi pemahaman masyarakat tentang dikotomi di tubuh Paderi.

Kata kunci: redefinisi, Kaum Paderi, metodologi genealogis, rekonsiliasi

\footnotetext{
${ }^{1}$ Penulis adalah Alumni Universitas Teknologi Yogyakarta 


\section{A. Pendahuluan}

\section{Latar Belakang}

$\mathrm{P}$ luralisme selalu melahirkan gejalagejala konflik. Konflik Paderi adalah konflik masa lalu yang memiliki dampak jangka panjang, dari konflik internal etnis Minangkabau (Kaum Adat dan Kaum Paderi) hingga melibatkan dua etnis besar Sumatera; Minangkabau dan Batak. Hal ini terjadi karena wacana yang muncul di tengah masyarakat khususnya Batak sebagai akibat pendidikan lokal yang rancu, yakni tambo dalam bahasa Minangatau turiturian dalam istilah Batak. Baik tambo maupun turi-turian tidak bisa dibuktikan mutlak kebenarannya sebab suatu peristiwa atau sejarah hanya dikisahkan dari mulut ke mulut. Munculnya buku berbasis legenda versi Batak (Tuanku Rao; Teror Agama Islam Mazhab Hambali di Tanah Batak 1816-1833) menyulut konflik tertutup antar dua etnis. Sejarawan mengklaim buku tersebut otentik sebab penulis merupakan keturunan langsung dari pelaku sejarah yakni Tuanku Lelo atau Idris Nasution serta data-datanya juga berasal dari koran Belanda terbitan tahun masa itu (artikel Oorsprong der Padaries-EeneSecte op de Westkust van Sumatra-termuat dalam Tijdschrift voor Nederlandsch Indie 1, No. 1, 1838) maupun sumber Residen Poortman, tokoh Belanda ahli Batak yang memiliki peran seperti Snouck Hurgronje di Perang Aceh.

Cerita turun temurun dari versi Batak dalam konflik Paderi adalah bahwa selama Perang Paderi, dakwah yang dilancarkan Kaum Paderi adalah dengan memerangi (membunuh) sehingga terjadi pembantaian massal yang menghabiskan seluruh dinasti Mauli Pagaruyung, separuh etnis Batak Mandailing (genosida) serta terbunuhnya raja Batak Singamangaraja XII. Pernyataan ini ditentang habis-habisan oleh pihak Minangkabau. Dari versi orang Minang, tidak ada pembantaian apapun. Belanda dan orang Batak dianggap berkomplot menulis sejarah yang menyudutkan orang Minang (Islam). Dari tambo orang Minang muncul tokoh Malin Marajo, seorang jawara Harimau Nan Salapan yang tidak bisa ditaklukan orang Batak sehingga memicu kedengkian bahwa orang Batak dikalahkan orang Minang. Entah mana yang benar lantaran masing-masing memiliki legenda sendiri. Sebagai jalan tengah dirumuskanlah gagasan ini dengan mengambil asumsi pertama tentang pembantaian yang (mungkin) dilakukan oleh bangsa Minang atau Kaum Paderi (meski tidak semua orang Minang adalah Paderi) terkait ada tidaknya peristiwa itu merujuk gerakan Wahhabi yang diklaim berhaluan radikal.

\section{Tujuan dan Manfaat}

a. Memberikan sumbangan terhadap ilmu pengetahuan berupa luaran teori yang menyajikan pilihan sejarah yang belum pernah disajikan di dalam makalah maupun buku-buku sejarah. Validitas terhadap teori ini bisa mengubah arah sejarah (change the course of history).

b. Memberi pemahaman kepada ma syarakat Indonesia tentang Kaum Paderi yang terdikotomi atau terpecah menjadi sekte-sekte fundamental berbasis kepemimpi nan surau dalam kerangka ke kuasaan Nagari (pemahaman imamah tentang konsepsi balad).

c. Meredam konflik tertutup antara etnis Minangkabau dan Batak.

\section{B. Realitas Konflik Tertutup Minangka bau-Batak}

$\mathrm{K}$ onflik tertutup ini sebenarnya sifatnya halus, sama seperti konflik tertutup etnis Jawa dan Sunda (legenda Perang Bubat). Namun menilik stereotipe orang Sumatra yang keras bisa jadi konflik tertutup memiliki potensi menjadi konflik terbuka, apalagi bila didasari dalih ras dan ideologi (Perang Paderi merupakan kampanye jihad) serta dendam yang terpendam sejak Perang Paderi berakhir. Bila akar pemecahan masalah tidak dibangun, maka wacana konflik akan terus berlanjut hingga bergenerasi, atau tidak pernah bisa diselesaikan.

Permasalahan ini bergulir beberapa tahun lalu (antara 2007-2008), yakni setelah buku tulisan Ir. Mangaraja Onggang Parlindungan (MOP) berjudul "Tuanku Rao: Teror Agama Islam Mazhab Hambali di Tanah Batak 1816-1833" cetakan kedua diterbitkan kembali oleh Penerbit LKiS Yogyakarta pada bulan Juni 2007. Buku ini 
menjadi wacana perdebatan dan diskusi di kalangan akademisi dan budayawan terutama tentang sejarah Batak (Seminar "Perang Paderi, 1803 - 1838.Aspek Sosial Budaya, Sosial Psikologi, Agama dan Manajemen Konflik" di Arsip Nasional RI, Jakarta, 22 Januari 2008). Sifat halus konflik tertutup ini dibuktikan dengan budaya santun yang mewakili intelektualitas etnis terkait. Bangsa Sumatra diakui sebagai bangsa berbudaya, terutama dalam ranah kesusasteraan. Sebagaimana pantun dibalas pantun, maka buku pun dibalas dengan buku. Alhasil, cetakan pertama buku Tuanku Rao karya MOP dibalas oleh Hamka dengan buku berjudul "Antara Fakta dan Khayal-Tuanku Rao"oleh Penerbit Bulan Bintang Jakarta 1974, yang isinya membantah total buku tulisan MOP. Bahkan Hamka menyebut data di buku MOP $80 \%$ bohong, $20 \%$ meragukan. Hal ini berkaitan dengan tidak adanya pembantaian yang dilakukan pasukan Paderi di tanah Batak, pemerkosaan dan perbudakan terhadap wanita Batak (menurut sumber turi-turian, wanita Batak banyak yang tidak cantik sebab yang cantik dipancung atau diperkosa dan dijadikan budak oleh pasukan Paderi), serta asal-usul Tuanku Rao yang menurut MOP adalah anak hasil hubungan gelap antara Gana Boru Sinambela (putri Singamangaraja IX) dengan paman kan dungnya, Gindoporang Sinambela (adik dari Singamangaraja $X$ ). Hamka menyebut sumber Belanda, J.B. Neumann, Kontelir $\mathrm{BB}$, yang menyebut bahwa Tuanku Rao berasal dari Padang Matinggi, bukan orang Bakkara (Batak) seperti data dalam buku MOP. Sumber Neumann, Residen T.J. Willer mengonfirmasinya (Hal. 239). Kurang kuatnya data buku itu menurut Hamka sebab setiap kali ditanya mengenai datadata buku tulisannya, MOP hanya menjawab, "Sudah dibakar" (Detik Forum.com).

Bila cetakan pertama buku karya MOP dibantah Hamka, maka cetakan keduanya diikuti buku "Greget Tuanku Rao" karya Basyral Hamidi Harahap yang terbit tahun 2007 juga. Namun buku "Greget Tuanku Rao" justru memperkuat tulisan MOP yang secara garis besar membenarkan telah terjadi pembantaian oleh pasukan Paderi semasa Perang Paderi berlangsung hingga pasukan Paderi meninggalkan tanah Batak karena wabah penyakit. Praktis kedua buku tersebut memicu nasionalisme ke-Batak-an dan memicu konflik tertutup (menghidupkan dendam masa lalu).

Bisa dikatakan buku Hamka adalah upaya atau solusi untuk meredam meluasnya konflik karena terpicu buku karya MOP. Memang tidak sepenuhnya buku karya Hamka tersebut bertendensi menjadi solusi rekonsiliasi, hanya sebagai usaha difensif terhadap labelisasi kekejaman bangsa Minang (ethnic issue), namun setidaknya usaha ini bisa dikatakan berani lantaran Hamka mempertaruhkan nama besarnya dengan menyatakan kebohongan dalam tulisan MOP. Secara umum tidak ada upaya rekonsiliasi yang benar-benar diwujudkan bahkan diwacanakan, sebab hal ini berkaitan dengan pembenaran cerita masing-masing dan sifat halusnya konflik tertutup antara etnis Minangkabau dan Batak. Redefinisi Kaum Paderi merupakan tawaran solusi rekonsiliasi sebab hal ini menjadi akar pola pikir masyarakat yang perlu diubah lantaran masih tumpang tindih terhadap legenda.

\section{Redefinisi Kaum Paderi Melalui Metodologi Genealogis Foucauldian}

$\mathrm{G}$ agasan mengenai redefinisi ini timbul lantaran banyaknya data yang tumpang tindih mengenai kebenaran Perang Paderi, terutama mengenai siapa yang paling bertanggung jawab atau menjadi tokoh sentral selama dakwah agresif Paderi. Apakah Paderi merupakan satu organisasi besar yang dipimpin Imam Bonjol dan melakukan kampanye dakwah berupa pelenyapan dinasti Mauli Pagaruyung di Kototangah, pembantaian etnis Batak, pemerkosaan dan perbudakan wanita bangsawan Mauli dan wanita Batak, serta pembunuhan raja Batak Singama ngaraja XII?

Dalam pandangan Foucault, genea logi atau sejarah selalu ditulis dari perspektif masa kini. Genealogi berusaha mengin dentifikasi hal-hal yang menyempal (accidents), mengidentifikasi penyimpanganpenyimpangan yang kecil (the minute deviations)'. Genealogi memfokuskan diri pada retakan-retakan, pada kondisi-kondisi sinkronik dan pada tumpang tindihnya pengetahuan yang bersifat akademis dengan kenangan-kenangan yang bersifat lokal (Foucault dan Lechte via Yudi Latif, 2012). 
Metodologi genealogis ini menem patkan keadaan sinkronik (perubahan pada saat-saat tertentu) yang dipengaruhi hegemoni eksternal kerangka sejarah subjektif, seperti pola instrumentalis media ataupun kekuasaan suatu pemerintahan (regime) dalam membangun citra suatu komunitas masyarakat yang dianggap 'berbahaya', dalam kerangka waktu yang diakronik (lama-sinambung). Sejarah selalu memiliki pola yang sama, hanya dimensinya (tempat dan waktu) yang berbeda. Metodologi genealogis ini memandang pola fenomena sosial masa kini sebagai pijakan kesamaan pola fenomena sosial di masa lalu. Melalui metodologi genealogis ini data yang dibandingkan antara lain: a) Konsep kekuasaan nagari yang mirip dengan struktur organisasi massa (ormas) serta pemahaman konsep imamah dalam kerangka balad (nagari), b) Labelisasi oleh rezim melalui alat instrumentalis media sebagai pembangun opini publik seperti dalam kasus Islam Jamaah (Ludhy Cahyana, Islam Jamaah: Di Balik Pengadilan Media Massa, 2003).

Dalam kebudayaan Minangkabau sistem pemerintahan masyarakat diatur secara otonomi dalam batas kekuasaan konfederasi empat suku dan membentuk apa yang dinamakan nagari (citystate). Pemimpin nagari tadi dipilih dalam sidang mufakat di balairung yang dikenal dengan istilah penghulu (A. A. Navis, 1999:4). Pemerintah Belanda menyebut sistem pemerintahan nagari ini sebagai republikrepublik kecil sebab ada kekuasaan yang lebih besar di atas otonomi nagari yang mengatur masyarakat Minangkabau dalam ranah negara atau alam Minangkabau yang terpusat di Tanahdatar, Kerajaan Paga ruyung. Tiap penghulu nagari menjadi pemimpin tertinggi internal nagari dalam urusan politik, sosial dan agama, sehingga penghulu nagari juga menjadi kepala surau. Dalam satu kawasan nagari hanya boleh ada satu surau. Dengan demikian surau suatu nagari bisa berbeda ideologinya dengan surau di nagari lain, sebab independensi dan otonomi kekuasaan penghulu atas nagari yang bahkan Rajo Alam Pagaruyung tidak berhak atasnya. Umumnya agama Islam di seluruh nagari di Minangkabau adalah agama adat (adat basandi syarak, syarak basandi Kitabullah), namun persebaran sekte-sekte baru tidak menimbulkan konflik bahkan boleh membangun surau sendiri, sampai mun culnya kelompok reformis yang dilabeli Pemerintah Kolonial sebagai 'Kaum Paderi' (merujuk radikalisme Tuanku Nan Renceh yang membunuh bibinya karena tidak mau salat dan makan sirih).

Konsep kekuasaan nagari di Minangkabau masa itu yang merepre sentasikan ideologi surau tak jauh berbeda dengan konsep keormasan di masa kekinian. Di awal abad XX, gerakan Islam dari embrio SDI (Sarekat Dagang Islam) terpecah menjadi beberapa partai maupun organisasi Islam karena perbedaan prinsip para petingginya. Kita sekarang melihat Islam terpecah ke dalam ormas yang secara ideologi mungkin sejalur namun secara pragmatis mereka berbeda baju dan jiwanya. Bahkan sekte Islam Puritan yang ada di Indonesia secara garis besar dibagi ke dalam tiga domain yakni Wahabi, Salafi dan Islam Jamaah. Kiprah dua aliran (Wahabi dan Salafi) diklaim sebagai aliran Islam transnasional dan terbukti menjadi domain ormas seperti Partai Keadilan Sejahtera (PKS) dan Hisbut Tahrir Indonesia (HTI) dimana hierarki kepemimpinan utama berada pada kontrol di luar wilayah Indonesia (KH. Abdurrahman Wahid, 2009). Ketiganya bisa disebut sebagai Islam Puritan (merujuk gerakan pemurnian Kaum Paderi) sebab domain sekte ini menolak ajaran tradisi dan akulturasi (bid'ah, khurafat, syirik, takhayul), menolak taklid, dan lebih literalis (pemahaman ayat secara tekstual). Ketiga domain ini juga memandang pentingnya konsep imamah. Dan pada kenyataannya, kesamaan ideologi, pemahaman tekstual, serta konsep imamah tetap mendikotomi ketiganya ke dalam sekte terpisah.Kenapa? Realitas ini yang mungkin juga terjadi di masa Paderi dan metodologi genealogis memandang fenomena tersebut sebagai variabel pola pembanding untuk melihat sejarah dengan perspektif masa kini.

Di masa awal dakwah Kaum Paderi muncul nama-nama pelopor seperti Haji Miskin, Haji Sumanik serta Haji Piobangpada tahun 1803. Baru setelah itu nama Tuanku Nan Renceh, seorang penghulu nagari Kamang mencuat karena dikenal dengan keradikalannya. Dakwahnya pun mendapat pertentangan dan menimbulkan konfrontasi sehingga pusat gerakan Paderi di Kamang dipindah ke Pandai Sikat (Wikipedia). Paderi adalah 
gerakan dakwah yang diklaim radikal karena terpengaruh paham Wahhabi merupakan ideologi Islam literalis yang mengutamakan konsep baiat (keamiran atau imamah). Namun kenyataannya dari sekian tokoh ulama Paderi sejak awal gerakan ini muncul hanya Peto Syarif yang dibaiat menjadi Imam, dan itu di nagari Bonjol. Kalau memang Paderi adalah satu organisasi dakwah yang memegang teguh konsep "halalnya hidup jamaah dengan membaiat seorang amir", kenapa sejak awal gerakan ini muncul, tiga haji pelopor itu tidak membaiat salah satunya, atau jamaah Paderi membaiat Tuanku Nan Renceh sebagai amir? Fakta ini menunjukkan perbedaan atau bahkan adanya dikotomi di tubuh Paderi. Padahal nama Peto Syarif juga muncul setelah tahun 1815, yakni tahun pembantaian dinasti Mauli Paga ruyung. Dalam buku Tuanku Imam Bonjol karya Sjafnir Aboe Nain oleh Penerbit Esa tahun 2008, TIB adalah penerus Tuanku Nan Renceh yang wafat di Mejan-Kamang tahun 1832. Data ini kurang masuk masuk akal melihat Tuanku Nan Renceh yang menjadi pemimpin Paderi tidak disebut Imam. Bagi kaum literalis, konsep imamah bukan hanya isu sunnah, namun mutlak wajibnya. Fakta gelar ini menunjukkan tidak ada relasi antara Imam Bonjol dan Tuanku Nan Renceh.

Berdasarkan konsep imamah atau keamiran, dalam satu negara (nagari/balad) hanya boleh ada satu amir yang dibaiat. Perbedaan konsep kekuasaan antar nagari ini menunjukkan absolutisme kekuasaan nagari sebagai balad. Hal ini yang menjadi dasar mengapa Peto Syarif dibaiat sebagai Imam di nagari Bonjol dan menjadi fakta adanya perbedaan ideologi di tubuh Paderi sendiri, yang dengan kata lain Kaum Paderi bukanlah satu kesatuan persaudaraan dakwah, bukan satu kelembagaan otokrasi, bukan pula kesatuan gerakan terorisme, namun merupakan penamaan atau labelisasi yang lebih merujuk pada tujuan politik devide et impera Pemerintah Kolonial Belanda dengan melabeli gerakan ini sebagai gerakan radikal karena mayoritas ulama pelopornya baru kembali dari Mekah yang telah dikuasai dinasti Saud (pengamat Barat menyebutnya kelompok Wahhabi) serta melihat radikalisme satu tokoh (Tuanku Nan Renceh) dengan maksud agar seluruh gerakan Islam Puritan di Minang kabau musnah.
Secara antropologis Tuanku Nan Renceh tidak bisa mewakili stereotipe orang Minang ataupun Muslim puritan. Keradikalan Tuanku Nan Renceh tidak bisa menjadi variabel kekejaman kelompok Islam Puritan yang dipelopori Bangsa Minang, sehingga apabila memang terjadi konfrontasi fisik di Tanah Batak, perkosaan dan perbudakan, pembantaian etnis Mandailing, serta pem bunuhan Singamangaraja XII, tidak bisa diklaim semua itu perbuatan Bangsa Minang, kaum muslim puritan atau Tuanku Imam Bonjol karena adanya dikotomi Kaum Paderi. Sama seperti aksi terorisme oleh jaringan AI Qaeda, ISIS, atau kelompok JIL tidak bisa diklaim bahwa masyarakat Islam dunia (orang Arab, muslim bercelana menggantung, muslim berjenggot, muslimah bercadar dil) yang bertanggung jawab atas aksi teror tersebut.

Mungkin sejarah tulisan Belanda perlu direvisi melihat kasus labelisasi serupa pernah menerpa kelompok Islam Jamaah (Lemkari/LDII) yang menggeliat pada de kade '60an dan '70an dimana peran instrumentalis media ataupun kekuasaan suatu pemerintahan (regime) mampu membangun citra komunitas masyarakat yang dianggap 'sesat'. Menurut Eriyanto (Islam Jamaah: Di Balik Pengadilan Media Massa, 2003, hal. 9-10) pemberitaan Tempo, Suara Karya, Jawa Pos, dan Sabili tidak proporsional dalam memberitakan LDII, selalu memberi label yang buruk dan mensugestikan bahwa organisasi dan ajaran yang dibawa LDII berbahaya dan sesat. Stigma yang tidak terjadi secara alamiah, tetapi dibentuk lewat pemberitaan media.

Hal inilah yang terjadi pada Kaum Paderi. Labelisasi oleh Pemerintah Belanda dan menciptakan stigma di tengah masyarakat yang membentuk opini bahkan legenda, tambo atau turi-turian yang diceritakan turun temurun dan menjadi sumber sejarah yang tanpa sadar masyarakat kala itu telah berhasil dipecah belah oleh politik devide et impera. Kita pada saat itu disetir oleh Belanda untuk menulis sejarah sendiri yang sesuai propaganda Belanda. Dengan metodologi genealogis, dua kasus di atas menghasilkan teori demikian.

Gagasan rekonsiliasi takkan terwujud tanpa ada campur tangan pihak yang membantu memberi pemahaman kepada masyarakat (terutama generasi muda) tentang redefinisi atau pilihan terbaru 
mengenai definisi Kaum Paderi. Pihak-pihak yang sangat berperan dalam pencapaian rekonsiliasi antara lain:

\section{a. Tokoh adat dan tokoh masyarakat}

Tokoh adat dan tokoh masyarakat di tanah Minang dan Batak memiliki peran sosio-politik dan sosio-spiritual yang memberi mereka kuasa atas terinisiasinya wacana rekonsiliasi. Adat masih memandang tokoh masyarakat dan tokoh adat (tetua adat atau wali nagari) sebagai otoritas tertinggi dalam memutuskan suatu perkara atau menginisiasikan sebuah gagasan krusial.

\section{b. Akademisi dan budayawan}

Para akademisi dan budayawan yang memiliki perhatian besar terhadap isu sejarah memiliki akses sebagai pembicara atau garda depan dalam menyampaikan gagasan Redefinisi Kaum Paderi terhadap masyarakat luas, khususnya masyarakat Minangkabau dan Batak. Peran sebagai "cendekiawan" mampu meyakinkan masyarakat melalui pemikiran ilmiah dan logis terkait redefinisi Kaum Paderi.

\section{c. Pemerintah}

Pemerintah dalam hal ini adalah pihak yang menjadi penengah atau mediator dalam wacana rekonsiliasi antara etnis Minangkabau dan Batak terkait sejarah masa lalu, dan juga pemerintah yang menjadi akses utama tersiarnya gagasan Redefinisi Kaum Paderi kepada masyarakat Indonesia bahkan dunia, dengan menyajikan pilihan sejarah mengenai dikotomi di tubuh "Kaum Paderi".

Banyak hal bisa dilakukan terkait wacana rekonsiliasi pasca "Perang Paderi". Beberapa langkah strategis berikut bisa menjadi pertimbangan untuk diimplementa sikan guna mencapai rekonsiliasi antara Minangkabau-Batak, antara lain:

a. Sosialisasi redefinisi Kaum Paderi kepada masyarakat khususnya Minangkabau dan Batak agar pemahaman tentang sejarah di masa lalu bisa memberikan pilihan yang bijak dengan mengambil jalan tengah antara dua kepercayaan masyarakat yang berbeda. Sosialisasi akar rumput ini bisa diinisiasikan oleh tokoh adat dan tokoh masyarakat Minang dan Batak. b. Seminar budaya yang tujuannya mensosialisasikan redefinisi Kaum Paderi oleh akademisi dan budayawan tanpa tendensi egoisme terhadap legenda masing-masing pihak.

c. Revisi kurikulum oleh pemerintah untuk memasukkan pilihan sejarah mengenai redefinisi Kaum Paderi sebagai akar solusi rekonsiliasi masyarakat Minang-Batak.

\section{Kesimpulan}

$\mathrm{K}$ onflik merupakan produk perbedaan atau keanekaragaman budaya yang menajam karena adanya kekuasaan yang menyusup ke bentuk hubungan sosial itu. Pemerintah Belanda sebagai pihak ketiga dalam Konflik Paderi menjadi pemenang di akhir karena propagandanya mulus. Tambo atau turi-turian sebagian besar bisa saja disusupi propaganda Pemerintah Kolonial sehingga produkproduk legenda masyarakat menjadi rancu, bahkan buku sejarah yang menjadi produk kekinian merupakan koalisi produk naskah Belanda dan naskah pribumi. Hasilnya tetap menciptakan perspektif berbeda antar masing-masing pihak baik Minang maupun Batak. Kesimpulannya, pihak penjajah berhasil memecah belah kita melalui produk budaya lokal. Perbedaan kolektif ini bisa menajam menjadi konflik bila akar solusi tidak dibangun untuk meruntuhkan pola pikir yang tumpang tindih berdasarkan legenda. Redefinisi Kaum Paderi Melalui Metodologi Genealogis Foucauldian ini menjadi akar solusi konflik tersebut yang diharapkan bisa mengubah pola pikir primordial dan menuntun pada rekonsiliasi.

Secara implementatif, redefinisi ini bisa berhasil menuntun pada rekonsiliasi jika pihak-pihak terkait memahami peranannya sebagai pelopor rekonsiliasi melalui sosialisasi, seminar kebudayaan, bahkan revisi kurikulum sejarah mengenai sejarah Kaum Paderi.

Kondisi yang diharapkan bisa tercapai secara global melalui sosialisasi redefinisi Kaum Paderi dengan pilihan teori sejarah yang baru adalah adanya rekonsiliasi etnis Minangkabau-Batak. Lunturnya pola pikir primordial menjadi titik tolak dimulainya rekonsiliasi. Rekonsiliasi mungkin satu kata yang ringan namun bermakna sangat dalam. Kita bisa menapaki jejak peradaban 
secara damai sampai bergenerasi jika kita yang memulai kata "maaf" apabila pernah terjadi konflik berdarah di masa lalu dan tidak mewariskan dendam dengan legenda yang tumpang tindih kebenarannya. Istilah rekonsiliasi hanyalah ruang publik untuk mengucap kata maaf dan menerima maaf tanpa memandang kebenaran subjektif.

\section{Daftar Pustaka}

Cahyana, Ludhy. 2003. Islam Jamaah di Balik Pengadilan Media Massa: Suatu Analisis Mengenai Pembunuhan Karakter Terhadap Lemkari/LDII. Yogyakarta: Benang Merah. HAMKA. 1961. Pengaruh Muhammad Abduh di Indonesia: Pidato Pengukuhan Gelar Doctor HonorisCausa dari Universitas Al-Azhar Mesir pada 21 Januari 1958 (edisi digital tahun 2008). Jakarta:Tintamas.

http://pustakamarola.wordpress.com (dari tulisan-tulisan Suryadi; Dosen dan peneliti pada Opleiding Talen en Culturen van Zuidoost-Azië en Oceanië, Universiteit Leiden, Belanda)

http://www.basyral-hamidy-harahap.com/blog/index.php?itemid=43

Ilusi Negara Islam: Ekspansi Gerakan Islam Transnasional di Indonesia (2009). Jakarta: The Wahid Institute.

Latif, Yudi. 2012. Inteligensia Muslim dan Kuasa: Genealogi Inteligensia Muslim Indonesia Abad Ke-20(edisi digital). Jakarta: Yayasan Abad Demokrasi.

Navis, A.A. 1999. Yang Berjalan Sepanjang Jalan (Kumpulan Karangan Pilihan). Jakarta: Grasindo.

Internet

www.detikforum.com

www.id.wikipedia.org 